\title{
Preliminary Phytochemical and Toxicity Studies of Aqueous Leaf Extract of Sida corymbosa Plant
}

\author{
John Maiganga Bakut*, Yohanna Adamu Tende, Aksavdwa Isaac Agyigra, Mojisola 0. Tende, \\ Abdulkadir Umar Zezi, Nuhu Mohammed Danjuma
}

Department of Pharmacology and Therapeutics, Faculty of Pharmaceutical Sciences, Ahmadu Bello University, Zaria, Nigeria

Email: *maigangajohn88@gmail.com

How to cite this paper: Bakut, J.M., Tende, Y.A., Agyigra, A.I., Tende, M.O., Zezi, A.U. and Danjuma, N.M. (2020) Preliminary Phytochemical and Toxicity Studies of Aqueous Leaf Extract of Sida corymbosa Plant. American Journal of Plant Sciences, 11, 1991-1997. https://doi.org/10.4236/ajps.2020.1112140

Received: August 25, 2020

Accepted: December 11, 2020

Published: December 14, 2020

Copyright $\odot 2020$ by author(s) and Scientific Research Publishing Inc. This work is licensed under the Creative Commons Attribution International License (CC BY 4.0).

http://creativecommons.org/licenses/by/4.0/

\section{(c) (i) Open Access}

\begin{abstract}
Over centuries, Sub-Saharan Africans have been using Sida corymbosa leaf extract during labour with the claims that it aids and facilitates childbirth among others. This study aimed at preliminary investigating the phytochemical constituent as well as the safety. Fresh plant (leaves) specimen was harvested and identified. Aqueous Sida corymbosa leaf extraction was carried out and used for phytochemical evaluation and toxicity study. Thirteen (13) adult Wistar rats were divided into 3 groups of 3 animals $(n=3)$ each for the first phase of the toxicity study and treated with doses $(10,100$ and 1000$) \mathrm{mg} / \mathrm{kg}$ respectively and observed for 48 hours. Four groups consisting of 1 animal each $(n=1)$ were used for the second phase and treated with doses of (140, 225,370 and 600) $\mathrm{mg} / \mathrm{kg}$ respectively. Phytochemical screening revealed the presence of carbohydrates, alkaloids, flavonoids, tannins, saponins, cardiac glycosides, sterol, triterpenes and anthraquinones in the extract. The $\mathrm{LD}_{50}$ of the extract was found to be $471.17 \mathrm{mg} / \mathrm{kg}$. The results of this study show that the aqueous leaf extract of Sida corymbosa is slightly toxic with potentials for biological activities from phytochemicals present.
\end{abstract}

\section{Keywords}

Phytochemicals, Toxicity, Sida corymbosa

\section{Introduction}

The potentials of plants as traditional pharmacological agents cannot be overemphasized. The dependency on traditional medicines is of global proportions and increasing owing to high scarcity and costs of orthodox medicines. Myriads of plants are known to contain a variety of phytochemicals with wide spectrum 
of health benefits. Novel drug development is largely predicated on availability potential natural products [1]. However, some of the traditional interventions can precipitate detrimental consequences without proper scientific evaluations. Thus, this study was designed to evaluate the phytochemical constituents of Sida corymbosa plant as well as its toxicity using adult Wistar rats.

Sida corymbosa is a plant that grows in subtropical and tropical Africa, Southern Asia and Central [2]. It is a perennial herb of about $0.7 \mathrm{~m}$ high with numerous erect branches. Leaves are oval, dentate, about $6.5-7.5 \mathrm{~cm}$ long and 1 - $2 \mathrm{~cm}$ broad. The flowers are solitary and axillary. Its fruits are more or less globular and covered on top with golden hairs [3]. Inside the fruit are ovoid, black numerous seeds. The plant is a pan-tropical wild species, which grows around the roadside and on wastelands [4]. Its botanical classification is thus; Class: Equisetopsida, Subclass: Magnoliidae, Order: Malvales, Suborder: Rosanae, Family: Malvaceae, Genus: Sida Specie: Sida corymbosa [5]. Sida corymbosa have been reported to possess anti-ulcer and wound healing activities in rats [6] Dike et al. [7] have also reported protective and therapeutic effects of sida corymbosa ethanolic leaf extract against abnormal serum bilirubin and total proteins. This plant has also improved liver function. Acute toxicity studies of the ethanolic extract were reported to be above $5000 \mathrm{mg} / \mathrm{kg}$ body weight in rats [8]. Phytochemical screening of the plant carried out by Dike et al. [8] suggests a possible antioxidant and antimalaria properties owing to the presence of flavonoids and alkaloids. The leaves of Sida corymbosa may serve as a better supplement to $\mathrm{Na}^{+}, \mathrm{Fe}^{2+}, \mathrm{CU}^{2+}, \mathrm{Mn}^{-}, \mathrm{CO}^{2+}, \mathrm{SO}_{4}^{2-}$ and $\mathrm{Cl}^{-}$relative to the roots. The plant also possesses anti-haemorrhagic properties in rats [9]. However, the study carried out by Ezeugwunne et al. [10] showed a significant increase in serum levels of uric acid, urea and creatinine following treatment with Sida corymbosa with remarkedly decreased body weight in treated animals thus, the plant may have detrimental effect on the kidneys. The intake of the decoction of $S$. corymbosa leaf is reported to lower blood pressure and improves cardiac irregularity, fever, seizure, ophthalmia, rheumatism, leucorrhoea, painful micturition, gonorrhoea, colic and general debility [11]. The type, content, and proportion of substances used as herbal medicines may vary depending on ecological conditions of the plant's habitat [12]. Thus, this study focused on phytochemical and acute toxicity study of Sida corymbosa aqueous leaf extract collected locally.

\section{Materials and Methods}

\subsection{Plant Material}

Fresh Sida corymbosa leaves (Figure 1) above were harvested from the premises of Technical College, Zaria (August 2015) and presented to the herbarium in the Department of Biological Sciences, Ahmadu Bello University for identification. The plant specimen was identified by the taxonomist as malvaceae, while the specie is Sida corymbosa with local names; "broom weed in english" and "karkashin kwado in hausa". The identification voucher number 1049 was assigned and recorded. 


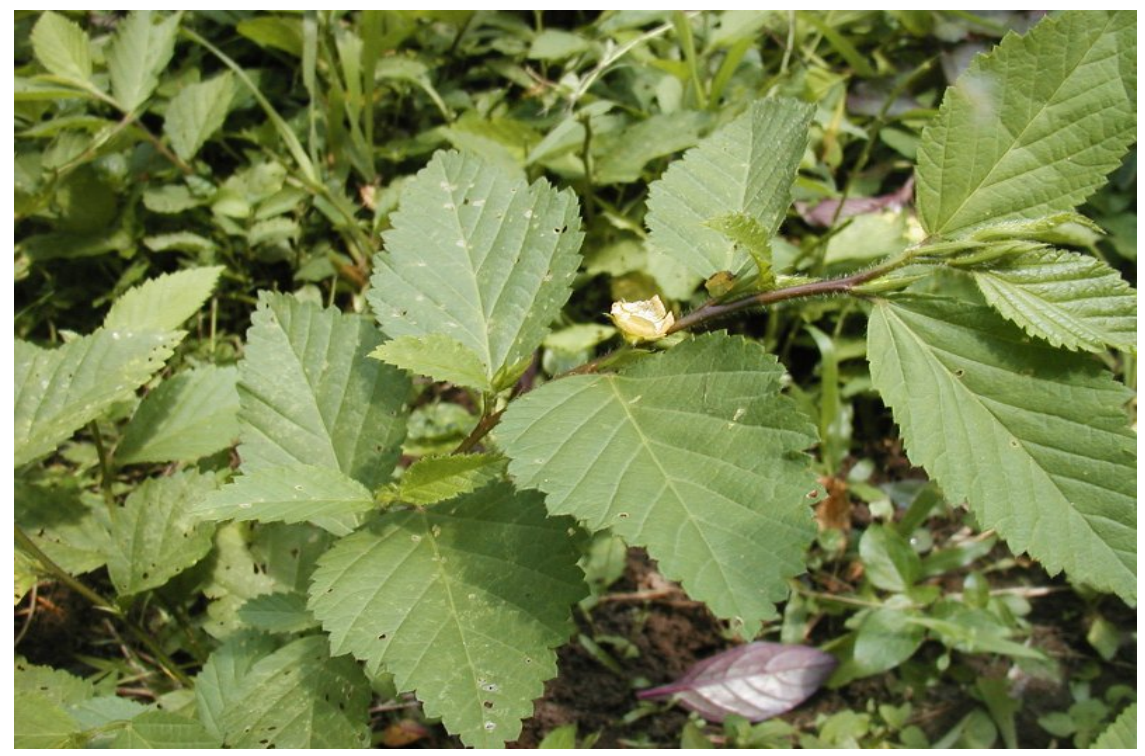

Figure 1. Sida corymbosa plant in its natural habitat.

\subsection{Animals}

Animals used for toxicity study (adult Wistar rats) weighing 160 - 200 g were bred in the Animal House of the Department of Pharmacology and Therapeutics, Ahmadu Bello University, Zaria. The animals were housed in white transparent plastic cages under standard conditions with free access to standard diet (Vital Feeds Ltd., Jos, Nigeria) and water. They were handled according to standard guidelines for use of laboratory animals (National Institute of Health, Public Health Service Policy on Humane Care and Use of Laboratory Animals, 2002).

\subsection{Aqueous Leaf Extraction}

Following plant specimen identification, the fresh leaves were harvested manually and rinsed in clean water then shade-dried for 10 days to allow moisture evaporation. Subsequently, it was taken to the Department of Pharmacognosy, Ahmadu Bello University Zaria for extraction. The air dried leaves of the plant were pulverized and $600 \mathrm{~g}$ of it soaked in $2 \mathrm{~L}$ of distilled water for 36 hours under constant agitation using the GFL shaker (No. $3017 \mathrm{MbH}$, Germany). The resultant mixture was decanted and filtered using Whatman's filter paper (No.1, Cat No. 1001 125) and concentrated under pressure in a rotary evaporator (R110 Buchi, Switzerland) at $60^{\circ} \mathrm{C}$ and further dried to a constant weight in a water bath set at $40^{\circ} \mathrm{C}$.

\subsection{Preliminary Phytochemical Screening}

Phytochemical analysis of the extract was performed according to the method of Sofowora [13] and Evans [14]. The extract was screened for carbohydrate, anthraquinones, triterpenes, sterol, cardiac glycosides, saponins, tannins, flavonoids and alkaloids. The screening was done at the Department of Pharmacognosy, Ahmadu Bello University, Zaria. 
The extract was dissolved in distilled water to obtain $1 \mathrm{mg} / \mathrm{ml}$ concentration and distributed into ten test tubes for the analysis of nine phytochemicals.

\subsubsection{Test for Carbohydrates}

\section{Molisch test}

To $5 \mathrm{mls}$ of the extract $4 \mathrm{mls}$ of molisch reagent was added in a test tube. This was followed by addition of $3 \mathrm{mls}$ concentrated sulphuric acid by allowing it to run gently on the side of the test tube [14].

Fehlings test

To 2 mls of extract, 5 mls of a mixture of Fehling solution A and B in the ratio of 1:1 was added and the mixture boiled for a few minutes.

\subsubsection{Test for Anthracene Derivatives (Bontrager's Test)}

To another test tube containing the extract, $5 \mathrm{ml}$ of chloroform was added and shaken for 5 mins. It was then filtered and the filtrate shaken with equal volume of $10 \%$ ammonia solution.

\subsubsection{Test for Unsaturated Steroid and Triterpene (Liebermann-Bucchard Test)}

To a test tube containing $5 \mathrm{mls}$ of the aqueous extract of $S$. corymbosa, $5 \mathrm{mls}$ of acetic acid anhydrate were added and mixed gently. $1 \mathrm{ml}$ of concentrated sulphuric acid was added down the side of the test tube to form a lower layer.

\subsubsection{Test for Unsaturated Sterols (Salkowski Test)}

To $3 \mathrm{mls}$ of the diluted aqueous extract of $S$. corymbosa, 2 - 3 drops of concentrated sulphuric acid were added to side of test tube.

\subsubsection{Test for Cardiac Glycosides (Keller-Kiliani Test)}

About $1 \mathrm{mg}$ of the aqueous extract of $S$. corymbosa was dissolved in $1 \mathrm{ml}$ of glacial acetic acid containing traces of ferric chloric solution. This was then transferred into a dry test tube and $1 \mathrm{ml}$ of concentrated sulphuric acid added down the side of the test tube to form a lower layer.

\subsubsection{Test for Saponin (Frothing Test)}

About $10 \mathrm{ml}$ of distilled water was added to $3 \mathrm{mls}$ of the aqueous extract of $S$. corymbosa. It was then shaken vigorously for about $1 \mathrm{~min}$. The tube was allowed to stand for about 30 mins and observed for honey comb froth [14].

\subsubsection{Test for Tannins}

To 5 mls of aqueous extract is added 3 - 5 drops of ferric chloride solution.

\subsubsection{Test for Flavonoids (Sodium Hydroxide Test)}

To $5 \mathrm{mls}$ of the aqueous extract a few drops of $10 \%$ sodium hydroxide were added. If a yellow coloration is noticed it indicates the presence of flavonoid.

\subsubsection{Test for Alkaloids (Dragendoff's Test)}

To $5 \mathrm{mls}$ of the aqueous extract few drops of Dragendoff's reagent were added. A reddish brown precipitate indicates the presence of alkaloid [14]. 


\subsection{Acute Toxicity Studies ( $\mathrm{LD}_{50}$ Determination)}

Acute toxicity studies were carried out using the method described by Lorke [15]. The experiment was done in two phases. In the first phase, the rats were divided into 3 groups of 3 rats each $(\mathrm{n}=3)$ and were treated with $10 \mathrm{mg} / \mathrm{kg}, 100$ $\mathrm{mg} / \mathrm{kg}$ and $1000 \mathrm{mg} / \mathrm{kg}$ of the aqueous extract of Sida corymbosa leaves orally. They were observed for signs of toxicity and death within the first 24 hours of administration. All animals treated with $1000 \mathrm{mg} / \mathrm{kg}$ of the aqueous extract died.

According to the method of Lorke [15], the second phase consisting of 4 groups containing a single rat each $(\mathrm{n}=1)$ were treated with $140 \mathrm{mg} / \mathrm{kg}, 225$ $\mathrm{mg} / \mathrm{kg}, 370 \mathrm{mg} / \mathrm{kg}$ and $600 \mathrm{mg} / \mathrm{kg}$ of aqueous extract of Sida corymbosa. The $\mathrm{LD}_{50}$ was calculated from the results of the final phase as the square root of the product of the lowest lethal dose and the highest non-lethal dose i.e. the geometric mean of the consecutive doses in which 0 and $100 \%$ survival rates were recorded:

$$
\begin{aligned}
\mathrm{LD}_{50} & =\sqrt{\text { Lowest lethal dose } \times \text { Highest non-lethal dose }} \\
& =\sqrt{600 \times 370}=\sqrt{222000}=471.17 \mathrm{mg} / \mathrm{kg}
\end{aligned}
$$

\section{Results and Discussion}

\subsection{Plant Yield}

The plant extraction yielded $36.4 \% \mathrm{w} / \mathrm{v}$ of dark brown, sweet smelling, soft and smooth textured product.

\subsection{Results of Phytochemical Screening}

See Table 1.

\subsection{Result of Acute Toxicity of Aqueous Leaf Extract of Sida corymbosa}

In the first phase, the result of zero percent lethality was found to be at 100 $\mathrm{mg} / \mathrm{kg}$ and above while that of $100 \%$ lethality was found to be $1000 \mathrm{mg} / \mathrm{kg}$. Then

Table 1. Phytochemical constituents of the aqueous leaf extract of Sida corymbosa.

\begin{tabular}{cc}
\hline CONSTITUENT & OBSERVATION \\
\hline Carbohydrate & Present \\
Anthraquinones & Present \\
Triterpenes & Present \\
Sterol & Present \\
Cardiac glycoside & Present \\
Saponin & Present \\
Tannins & Present \\
Flavonoids & Present \\
Alkaloids & Present \\
\hline
\end{tabular}


the second phase was carried out using the probit scale. The extract was given orally at doses of $140 \mathrm{mg} / \mathrm{kg}, 225 \mathrm{mg} / \mathrm{kg}, 370 \mathrm{mg} / \mathrm{kg}$, and $600 \mathrm{mg} / \mathrm{kg}$. It was found that zero lethality was recorded at a maximum dose of $370 \mathrm{mg} / \mathrm{kg}$ and $100 \%$ lethality at a minimum dose of $600 \mathrm{mg} / \mathrm{kg}$. $\mathrm{LD}_{50}=471.17 \mathrm{mg} / \mathrm{kg}$.

\subsection{Discussion}

Investigation on the phytochemical compounds of Sida corymbosa leaf aqueous extract revealed the presence of tannins, cardiac glycosides, triterpene, steroids, carbohydrate, saponins, flavonoids and anthraquinones. These phytochemicals are known to possess biological activities as well as defensive actions of the plants. There is also peculiarity in their mode of actions with constituents like tannins acting via iron deprivation alongside hydrogen bond and enzymatic activities. Flavonoids are known for their potent antioxidant properties as reported by Geetha [16], thus possessing the capacity for prevention or treatment of diseases associated with oxidative damages to membranes and DNA among others [17]. Saponins have been identified as among other things to elicit inhibitory actions on inflammation [17]. Tanins have been reported to have hypoglycemic activities [18]. Additionally, other constituents like flavonoids, steroids and terpenoids also possess antidiabetic properties [17].

The acute toxicity screening of a substance is an important toxicological investigation for an unknown substance. The $\mathrm{LD}_{50}$ which represents the individual dose required to kill fifty percent of a population of test animals is a very useful index for grading the acute toxicity of a substance. Aqueous leaf extract of Sida corymbosa is slightly toxic or can cause harm if consumed. This is important because the plant is currently being ingested and used among human population for various ethnomedical reasons. In conclusion, although the preliminary study of the plant showed the presence of vital phytochemicals, the toxicity study suggests the consumption of such plant as traditional remedies to be with caution until further research has been carried out. However, this study was limited to only aqueous extracts and only rats and not mice.

\section{Conflicts of Interest}

The authors declare no conflicts of interest regarding the publication of this paper.

\section{References}

[1] Esterhuyse, A.J., Farombi, E.O., Oguntibeju, O.O., Oyagbemi, A.A. and Salihu, M. (2015) Some Selected Medicinal Plants with Antidiabetic Potentials. In: Antioxidant-Antidiabetic Agents and Human Health, IntechOpen, London. https://doi.org/10.5772/57230

[2] Holm, L.G., Plucknett, D.L., Pancho, J.V. and Herberger, J.P. (1977) The World's Worst Weeds: Distribution and Biology. University Press of Hawaii, Honolulu.

[3] Ignacimuthu, S., Ayyanar, M. and Sankara-Sivaramann, K. (2006) Ethnobotanical Investigations among Tribes in Madurai District of Tamil Nadu (India). Journal of 
Ethnobiology and Ethnomedicine, 2, 25.

[4] Agyakwa, C.W. and Akobundu, I.O. (1998) A Handbook of West African Weeds. African Book Builders, International Institute of Tropical Agriculture, Ibadan, 352.

[5] Fries, R.E. (1965) Botanical Classification of Plants, Missouri Botanical Garden. http://www.tropicos.org/sida/2874

[6] John-Africa, L.B., Yahaya, T.A. and Isimi, C.Y. (2013) Anti-Ulcer and Wound Healing Activities of Sida corymbosa in Rats. African Journal of Traditional, Complementary and Alternative Medicines, 11, 87-92. https://doi.org/10.4314/ajtcam.v11i1.12

[7] Dike, C.C., Ezeonu, F.C., Maduk, H.C.C., Ezeokafor, E.N., Okpogba, A.N., Oguazu, E.C., Eyeghre, O.A. and Asebioyo, S.J. (2020) The Effects of Sida corymbosa Leaf Extract against Abnormal Bilirubin and Total Protein in Albino Rats by Carbon Tetrachloride (CCl4). Journal of Diseases and Medicinal Plants, 6, 39-46. https://doi.org/10.11648/j.jdmp.20200602.12

[8] Dike, C.C., Ezeonu, F.C., Maduk, H.C.C., Ezeokafor, E.N., Okpogba, A.N. and Oguazu, E.C. (2018) Hepatotherapeutic Potentials of Sida corymbosa (Wire Weed) Ethanolic Leaf Extract on Carbon Tetrachloride (CCl4)-Induced Acute Hepatotoxicity in Male Albino Rats. European Journal of Pharmaceutical and Medical Research, 5, 146-155.

[9] John-Africa, L.B. and Mercy, A. (2015) Evaluation of the Haemostatic Activities of Sida corymbosa in Rats. British Journal of Pharmaceutical Research, 5, 431-436. https://doi.org/10.9734/BJPR/2015/15676

[10] Ezeugwunne, I.P., Eriugo, R.C., Ogbodo, E.C., Oguaka, V.N., Analike, R.A., Madukwe, D.U.P., Okwara, E.C., Onyegbule, O.A. and Ezego, A.I. (2017) Effect of Sida corymbosa Leaf Extract on Serum Uric Acid, Urea and Creatinine Levels of Alloxan-Induced Diabetic Albino Wistar Rats. International Journal of Basic, Applied and Innovative Research, 6, 51-57.

[11] Food and Agriculture Organisation (2002) Cultural Practices. http://www.fao.org/in-action/accenting-the-culture-in-agriculture/en/

[12] Liu, W., Liu, J., Yin, D. and Zhao, X. (2015) Influence of Ecological Factors on the Production of Active Substances in the Anti-Cancer Plant Sinopodophyllum hexandrum (Royle) T.S. Ying. PLoS ONE, 10, e0122981. https://doi.org/10.1371/journal.pone.0122981

[13] Sofowora, A. (1996) Medicinal Plants and Traditional Medicine in Africa. Spectrum Books Ltd., Ibadan, 100-107.

[14] Evans, W.C. (2002) Pharmacopoieal and Related Drugs of Biological Origin. In: Evans, W.C. and Evans, D. Eds., Pharmacognosy, WB Saunders Co. Ltd., London, 374.

[15] Lorke, D. (1983) A New Approach to Practical Acute Toxicity Testing. Archives of Toxicology, 5, 275-287. https://doi.org/10.1007/BF01234480

[16] Geetha, B.S., Mathew, B.C. and Augusti, K.T. (1994) Hypoglycemic Effects of Leucodelphinidin Derivative Isolated from Ficus bengalensis (Linn.). Indian Journal of Physiological Pharmacology, 38, 220-222.

[17] Emmanuel, S., Rani, M.S. and Sreekanth, M.R. (2010) Antidiabetic Activity of Cassia occidentalis Linn. in Streptozotocin-Induced Diabetic Rats: A Dose Dependent Study. International Journal of Pharma and Bio Sciences, 1, 14-25.

[18] Rhemann, A.V. and Zaman, K. (1989) Medicinal Plants with Hypoglycemic Activity. Journal of Ethnopharmacology, 26, 1-55. https://doi.org/10.1016/0378-8741(89)90112-8 